\title{
Anthophyllite Asbestos: The Role of Fiber Width in Mesothelioma Induction. Part 3: Studies of American and Japanese Anthophyllite Asbestos - Additional Supportive Evidence
}

\author{
Edward B. Ilgren ${ }^{1} \&$ John A. Hoskins ${ }^{2}$ \\ ${ }^{1}$ Visiting Professor of Neuropathology \& Expert Investigator in Environmental Neurotoxicology, University of \\ Tarapaca, Chile. Formerly, University of Oxford, Faculty of Biological \& Agricultural Sciences, Department of \\ Neuropathology, Oxford, UK \\ ${ }^{2}$ Independent Consultant, Haslemere. UK. Formerly, Medical Research Council, Leicester, UK \\ Correspondence: Dr. E. B. Ilgren, Visiting Professor of Neuropathology \& Expert Investigator in Environmental \\ Neurotoxicology, University of Tarapaca (UTA), Arica 1000000, Chile. Tel: 56-58-2-215420-124. E-mail: \\ dredilgren@aol.com
}

Received: August 20, 2018

doi:10.5539/ep.v8n1p1
Accepted: November 12, $2018 \quad$ Online Published: December 11, 2018

URL: https://doi.org/10.5539/ep.v8n1p1

\begin{abstract}
The largest anthopyllite deposits in the world are found in Finland and it is from here that most of the commercial anthophyllite derives. However, other large deposits exist in both North America and Japan. Commercial production has existed in both these countries although not on a scale which matches the Finnish mines. Small deposits are known from several other countries but, apart from minor exploitation in India no significant mining has taken place. The North American deposits are primarily in the Eastern US states, mostly Maryland, Georgia and North Carolina although there was also extensive exploration in Alabama. In Japan, the major mining site was at Matsubase on the southermost island of Kyushu. Although these mines and attendant commercial concerns operated for decades and under conditions of high dust exposure no mesothelioma clusters are known from the mining areas.
\end{abstract}

Keywords: anthophyllite, fiber width, Japan, Matsubase, mesothelioma, pleural plaques, Eastern United States

\section{Introduction}

The link between asbestos exposure and mesothelioma formation was confirmed by Wagner et al. in 1960 for crocidolite (Wagner et al., 1960) and by 1972, if not before, for amosite (Selikoff, 1972). By contrast, in 1994, the ability of anthophyllite asbestos to cause mesothelioma was still questioned (Meurman et al., 1994). The epidemiological evidence thus underscores a significant difference in the ability of anthophyllite to cause mesothelioma from other types of amphibole asbestos. Ilgren and Hoskins (2018a,b) and many others before us (cited therein) based this largely upon differences in fiber width and durability.

This report provides further supportive evidence based on studies of the American and Japanese anthophyllite industry. The USA and Japan commercially mined, milled and distributed anthophyllite in significant quantities for nearly 100 years starting in the nineteenth century. Whilst this has created significant potential occupational, para-occupational and environmental exposure in both countries, there is no evidence of an attributable risk of mesothelioma in either. Numerous deposits of anthophyllite asbestos are found in both countries. Together with Finland these are the only countries which have, or had, a significant anthophyllite industry.

2. Anthophyllite Mineralogy: Determinants of Anthophyllite Asbestos Formation - Commonality between Finland and the United States

The relevance of the American observations to those made in Finland is underscored by their geo-tectonic, geological, and morphogenetic similarities well summarized by Lindgren (1925) who said: "It needs scarcely to emphasized how entirely similar the described occurrences from Fenno-Scandia ${ }^{1}$ are to the deposits..." in certain

\footnotetext{
${ }^{1}$ The Fennoscandian region includes Norway, Sweden and the north westernmost part of the U.S.S.R. (Ramsay, 1898).
} 
anthophyllite mining areas in the United States (also see Ramsey, 1898; King, 1967²; Wilk, 1953; Virta, 2015 comm.). Thus, the world's largest single deposit of anthophyllite asbestos occurs in the Karelides mountain in the eastern part of Finland (Hodgson 1986) where the tectonic-metamorphic conditions for its formation have been exceptionally favourable. Similarly, the macroscopic appearance of anthophyllite asbestos in most parts of the United States resembles that found Finland. Macroscopically, this is very different from crocidolite and amosite that arise within banded ironstone formations also called 'BIFs', highly reflective of their different modes of geological formation.

On a more basic level, Finnish and American anthophyllite asbestos deposits were originally geotectonically sheared and up-thrust through ancient opthiolitic lithospheres as lenses. This gives them their distinct geological appearance. The ophiolites, sheets of oceanic lithosphere, were transported onto continental margins under the cover of ancient but stable land masses (Hodgson, 1986). ${ }^{3}$

During mountain-folding and continuous pressure, these ophiolitic sheets stretched out and finally detached into "lenses" generally ellipsoid in shape (e.g for Finland, Aurola, 1954; for North Carolina, Conrad et al., 1963). The largest ellipsoids were commercially mineable and found in the largest quantities in Maryland, Georgia and North Carolina. The anthophyllite deposits are usually found as masses of randomly orientated cubic blocks of fiber. Exceptional deposits such as those found in a few parts of Alabama are veined or stratified (Hodgson 1986).

Säntii et al. (2006) believe granite intrusions are the key to altering the ultramafic rock to anthophyllite asbestos in Finland. This is probably the case in the United States as well. In Finland, commercially valuable anthophyllite asbestos only occurs when Maarianvaara granite is in immediate contact with the ultrabasic lenses (Aurola, 1954). These granitoid bodies add the silica and water needed for the alteration process (Virta, 2015 pers. Comm.) during regional high temperature - pressure metamorphism of ultramafic rocks and serpentinites (Aatos, 2015, pers. comm.).

Regional high temperature and pressure metamorphism is reflected in Finland and the United States (e.g. North Carolina) in several ways. Firstly, the terrain moving from the Eastern border of Finland westward to Paakilla changes from flat to prominent undulating hills. In the United states, taking North Carolina as an example, "The main area of the peridotite belt (in which anthophyllite forms) is coincident with the mountain section of the State" has a rugged nature that produces numerous cross ridges like "rungs on a ladder'. (Conrad et al., 1963)

In North Carolina, the abundance of water is also seen in "the mountain section of the State which falls within a distinct climatic zone associated with more rainfall than anywhere else east of the Rockies" (Conrad et al., 1963). Similarly, in Finland, the enumerable lakes surrounding Paakilla were clearly depicted in the maps shown in Ilgren and Hoskins (2018b) in our study of Finnish anthophyllite asbestos.

\section{American Anthophyllite}

The anthophyllite industry in the United States may be one of the first mining operations of the mineral in the New World, pre-dating "modern" Finnish mining and milling operations (Ilgren \& Hoskins, 2018a) by nearly 75 years (McCallie, 1910). It was certainly the oldest asbestos industry in the United States (Bangs, 1946; Avery et al., 1958). The first mention of the use of anthophyllite in the United States was apparently for lining fire proof chests with "stone paints" in 1837 in Maryland (Bangs, 1946). In 1858, the Johns Company began mining fibrous anthophyllite for use as asbestos insulation at the Ward's Hill quarry in Staten Island, New York (Betts, 2009).

Most of the anthophyllite in the United States is found in the Eastern part of the country. This is principally located within a discontinuous belt of mafic and ultramafic rocks that extend for more than 2,000 miles from western Newfoundland to east-central Alabama. The "belt" contains hundreds of small anthophyllite deposits but is particularly well developed in the Piedmont region of Alabama, Georgia, North Carolina and Maryland. The principal domestic sources of anthophyllite asbestos were from Georgia and North Carolina (Bangs, 1946; Conrad et al., 1963) though active early mining also took place in Maryland and extensive exploration in Alabama. The first

\footnotetext{
${ }^{2}$ An ancient Palaeozoic land mass called Laurasia embraced the eastern part of North America, Greenland, Scandinavia and the central part of Russia. The North American shield was at that time rotated close towards Europe (King LC, 1967)

${ }^{3}$ Those found in Finland are thought to be some of the oldest in the world (Säntti et al, 2006) as marked by relict chromite. Not surprisingly, chromite is also widespread in some of the larger anthophyllite asbestos deposits found in the United States and was even mined in some of them.

${ }^{4}$ King PB (1955) also said that "The main belt of ultramafic rocks in North Carolina in the Blue Ridge province is associated with a vast complex of Precambrian metamorphic and plutonic rocks "all being generally strongly folded".
} 
large-scale production of anthophyllite asbestos in the Eastern U.S. began in 1894 at Sal Mountain Georgia. (McCallie, 1910).

\subsection{Maryland}

\subsubsection{Mining, Milling and Health Related Information}

The largest anthophyllite containing ultramafic suite in the United States is known as the "Baltimore Complex" (Morgan, 1977). It extends $150 \mathrm{~km}$ from southeastern Pennsylvania across Maryland to northern Virginia through some heavily populated areas. Given its great size, it is not surprising that anthophyllite asbestos mining in Maryland has had a particularly long and interesting history. Thus, in 1916, the ship shortage of the first World War cut off the supply of chemical filter tremolite from Italy which prompted Mr. Fred Mett in Maryland to start to develop the local commercial deposits of amphibole asbestos, particularly anthophyllite (Mett, Asb J 1929). With the cooperation of the USGS and the Bureau of Standards, Mett developed a filter fiber superior to the Italian product (Bangs, 1946) and thus became the pioneer in the United States in the preparation of asbestos filter fiber for use in the Gooch crucible (Asb J 1929). Indeed, after 1880, the history of asbestos mining in Maryland was the history of the Powhatan Mining Corporation incorporated in 1923 by Mr. Fred Mett. The anthophyllite asbestos mining company operated in Baltimore for nearly 70 years (see references to Mett in Bangs, 1946). Mett initially worked the Jenkins Asbestos Mine at Pylesville, the largest and most important asbestos deposit in Maryland (Bangs, 1946) and the first to provide ore to Powhatan. The steadily rising demand for the new filter product caused Mett to prospect extensively through Maryland (Bangs, 1946). As these mines were progressively exhausted, he continued to prospect other parts of the United States. After 1941, Powhatan received major shipments of anthophyllite from Sal Mt Georgia and then in the mid-1950s, others from North Carolina. Powhatan mined asbestos in North Carolina more or less continuously from 1918 to 1963 through at least 13 deposits but these apparently yielded considerably less than a hundred to several thousand tons of ore. Powhatan also prospected anthophyllite from Alabama but the mining yield was too low to be of commercial value.

In Maryland, anthophyllite was mined successfully at many points in a North East to a South West direction conforming to a belt of igneous rocks (Mett, see Bangs, 1946). The weathering ${ }^{5}$ and softening of the amphibole determined the depth to which the mineral could be worked (also see 'Weathering' below). Indeed, where the anthophyllite had not been weathered, it was hard and of little or no value. We could not find information regarding the industrial hygiene and epidemiological parameters of the Maryland mines or the diverse mines outside of Maryland that provided anthophyllite asbestos to Powhatan. ${ }^{6}$

The Powhatan mill apparently ran from 1918 to 1984 (Bangs, 1946). We could not find epidemiological information. By 1946, fifty men apparently ran the operation (Bangs, 1946). There is only anecdotal information (Horton, T. Baltimore Sun, 1977) [“Asbestos processor finds itself centre of attention"] regarding the dust conditions in the Powhatan mill. We have no historical fiber measurements. However, historical accounts suggest the fiber levels were very high as evidenced by multiple alleged violations of the existing air quality standards (Baltimore Sun, 1977). There was said to be no apparent exposure to the residents of the community at Woodlawn around the mill (Baltimore Sun, 1977). The area was subject to an ATSDR health consultation in $2011^{7}$.

\footnotetext{
${ }^{5}$ On outcrop, the peridotites exhibit unique characteristics and are easily distinguished from the surrounding gneisses and schists. ... They are massive and more resistant to weathering than rocks with a well-developed schistosity. ... The outcrops have a characteristic dull-brown or rusty color, which is the result of the weathering of olivine. (Conrad et al., 1963)

${ }^{6}$ http://www.atsdr.cdc.gov/asbestos/more_about_asbestos/health_consultation/ Tremolite Asbestos Health Consultation. U.S. Environmental Protection Agency, Powhatan Mining Company Site. EPA to Conduct Air and Soil Sampling -- Gwynn Oak, Baltimore County, MD. POWHATAN MINING COMPANY WOODLAWN, BALTIMORE COUNTY, MARYLAND - NOVEMBER 14, 2011 - This concludes the health consultation process for this site, unless additional information is obtained by ATSDR which, in the Agency's opinion, indicates a need to revise or append the conclusions previously issued. Mr. Jack Kelly On Scene Coordinator Removal Response Program; Trish Taylor or David Polish, EPA Community Involvement Coordinators. (800) 553-2509 taylor.trish@epa.gov polish.david@epa.gov; Jack Kelly, EPA On-Scene Coordinator, (215) 814-3112 or kelly.jack@epa.gov (Mail Code 3HS31) USEPA -Region 31650 Arch Street Philadelphia, Pennsylvania 19103-2029; Arthur O’Connell, Chief, MDE Controlled Hazardous Substance (CHS) Enforcement Division, (410) 537-3493 or aoconnell@mde.state.md.us

${ }^{7}$ Domestic exposure was subsequently assessed in an ATSDR health consultation in 2011. This concluded that "Through the course of several site visits and the review of previous testing data, EPA determined that the on-site asbestos could pose a potential threat to human health and will begin actions to address the site." One home tested positive. "The tested home is the closest residential structure to the former manufacturing facility. Many years ago, prior to its conversion to a home, the building was used to dry products manufactured at the facility, and personnel changed clothing and washed in the building. Recently, asbestos-containing fill material was discovered adjacent to the home's foundation. You shared preliminary results from mid-October testing ofthe home with ATSDR the week of October 24,2011. Samples from
} 
Mett said the high turnover at the Powhatan facility made it impossible to keep medical records (Baltimore Sun, 1977). However, some heath related information was provided by a former company examining physician (Baltimore Sun, 1977). ${ }^{\mathbf{3}}$. He said he only knew of three employees who had worked there for ten years and any observed lung abnormalities were related to smoking though possibly accentuated by the dust. Some have discussed the use of tremolite in addition to anthophyllite from several Maryland deposits but vast majority of the fiber processed was anthophyllite.'

Uses: Anthophyllite processed at the Powhatan Baltimore mill was hand-selected, cobbed, washed and concentrated by specially designed machinery, dry and wet milled, crushed through hammer impact and ultimately purified to a chemically stable state where it no longer showed any further loss upon continued ignition (Mett, see Bangs 1946). This made it highly suitable for laboratory work, particularly in chemical analysis and filtration i.e. the Gooch Crucible (1917 - 1918 Min. Yearbook). The prepared fiber was known as "Powinco" (Fig. 1).

Comparisons between Powinco, Italian tremolite, South Africa amosite and crocidolite clearly demonstrated the superiority of the Powhatan product (Bangs, 1946; Asb. J 1929). Powinco eventually found many uses beyond that as a filtration agent. As of 1929, this included its introduction into plastics; asphalitic and bituminous fire proofing; heat insulation; flooring; fire bricks; paints; furnace cement; retort cement; and waterproofing. By the 1960s, it was widely used as a filler and an absorbent and extender in Phenolic Molding Powders, Phenolic Resin Laminates, Melamine Resin Laminates, Cold-Molded Organic Plastics, Silicone Resin Laminates, Resinated Felts and Rubber Compounds. Its use was even extended to the rocket and missiles industry. As a consequence, the diversity of American manufacturers and industries that produced and sold Powinco became very impressive ${ }^{10}$. And even extended to the UK and other countries.

Mett (see Bangs 1946) said the "Asbestos Filter Fiber" "was used in most of the Government, State, City, Commercial and Industrial Laboratories in the U.S. of America. In 1965, Powinco was used for protection against acid corrosion by developing a formulation blending method that mixed anthophylite asbestos with traditional resins. In 1972, the Powminco Asbestos was used in hundreds of applications, from helping patch a crack in a swimming pool to reducing air pollution by serving as a media supplement in air filters (http://asbestosbooks.com/powminco.html)."

\subsection{Georgia: Mining, Milling and Health Related Information}

The Soapstone Ridge (SSR) is a prominent 26-square-mile body containing both fibrous and non-fibrous anthophyllite, cummingtonite, and tremolite (Hopkins, 1914; King, 1957; Vincent et al., 1990; Blake et al., 1982; Hodgson, 1986; Chaumba \& Murphy, 2013). It is the second largest ultramafic body in the Eastern United

\footnotetext{
stationary air monitors run in several different rooms, with oscillating fans and ceiling fans running, showed phase contrast microscopy equivalent (PCMe) asbestos air concentrations ranging from 0.0091 to 0.019 structures per cubic centimeter ( $\mathrm{s} / \mathrm{cc}$ ), with all fibers identified as anthophyllite, the main type of asbestos processed at the former plant. Microvac dust sampling showed very low or non-detectable levels of PCMe asbestos fibers. ... Because the recent indoor air sampling from the home adjacent to the Powhatan site indicated concentrations well above the health-based benchmark concentration, A TSDR concludes that long-term, continuous exposures to these levels could increase the risk of cancer to unacceptable levels. We recommend the home be cleaned thoroughly using wet methods, high efficiency particulate air (HEPA) vacuuming, and/or steam cleaning

${ }^{8}$ Bangs (1946) said "Fifty men were employed by the Powhatan company at the mines and mill and the daily production averages one carload of finished product. Three shifts were operated during the war but this was discontinued by 1945." The Baltimore Sun article (ca. 1975) said the work force varied from 6 to 12 workers depending on orders. The chest X-rays and pulmonary function tests of the workers, according to Mett, showed no abnormalities. However, according to a Dr Brecher who had been the company's examiner for six years, "lung abnormalities" were found in five or six workers who had spent several years in the mill. He said that everyone there was a heavy smoker so the findings could be due to a combination of the dust and the smoking. ... Only three current employees in the mill have worked there more than 10 years and only one for more than 15 years. Dr Brecher said he had no health records for employees before he started regular physical exams. Mett also said there had been so much turnover of employees during the life of the company that was non-union, that it would be impossible to keep track of the former employees." "There is no apparent exposure to Residents in Woodlawn to asbestos dust from Powhatan. The nearest resident aside from Mett lives several hundred yards away. The mineral comes in covered trucks and leaves in sealed bags. There are no visible emissions from the buildings into the air.

${ }^{9}$ There are reports that tremolite was mined at the Jenkins mine and periodically processed there. However, the extent of tremolite contamination is not clear though some believe it was not significant (Ross, 1981). Virta (Virta, 13 Nov 13, pers. comm). also said The 1939 Minerals Yearbook mentioned that although identified as anthophyllite for many years, the asbestos mined near Pylesville, MD, was identified definitely as tremolite. It stated that tremolite asbestos was the principal product of the Powhatan Mining Corp. from that location. In addition, some of the sources of asbestos sent to Powhatan from outside of Maryland e.g. Sall Mountain may also have contained tremolite.

10 "Powminco" Asbestos Filter Fiber was also sold to many users in the UK ranging from military, university, pharmaceutical, iron, gas, paint, steel alloy, brewery, dairy, sweetener, oil, pottery, motor engine, and distillery companies. It was thus stated that it was "widely used as a filler and an absorbent and extender in phenolic and polyester resins" and is "practically inert."
} 
States and is located within the Atlanta metropolitan area (Blake et al., 1982). The Georgia State Geologist believed the excavation of the SSR had a considerable potential for releasing fibers into the environment (Blake et al., 1982). He was asked by the Bureau of Mines in the 1970s about the possible effects on health of airborne particulate matter from the construction and excavation activities along the outcrop of this body that included highway cut-and-fill operations, grading of land sites, and tunneling operations (Blake et al., 1982). All of these were thought to be able to release quantities of mineral particulate matter including pieces of friable asbestos into the atmosphere or streams (Blake et al., 1982).

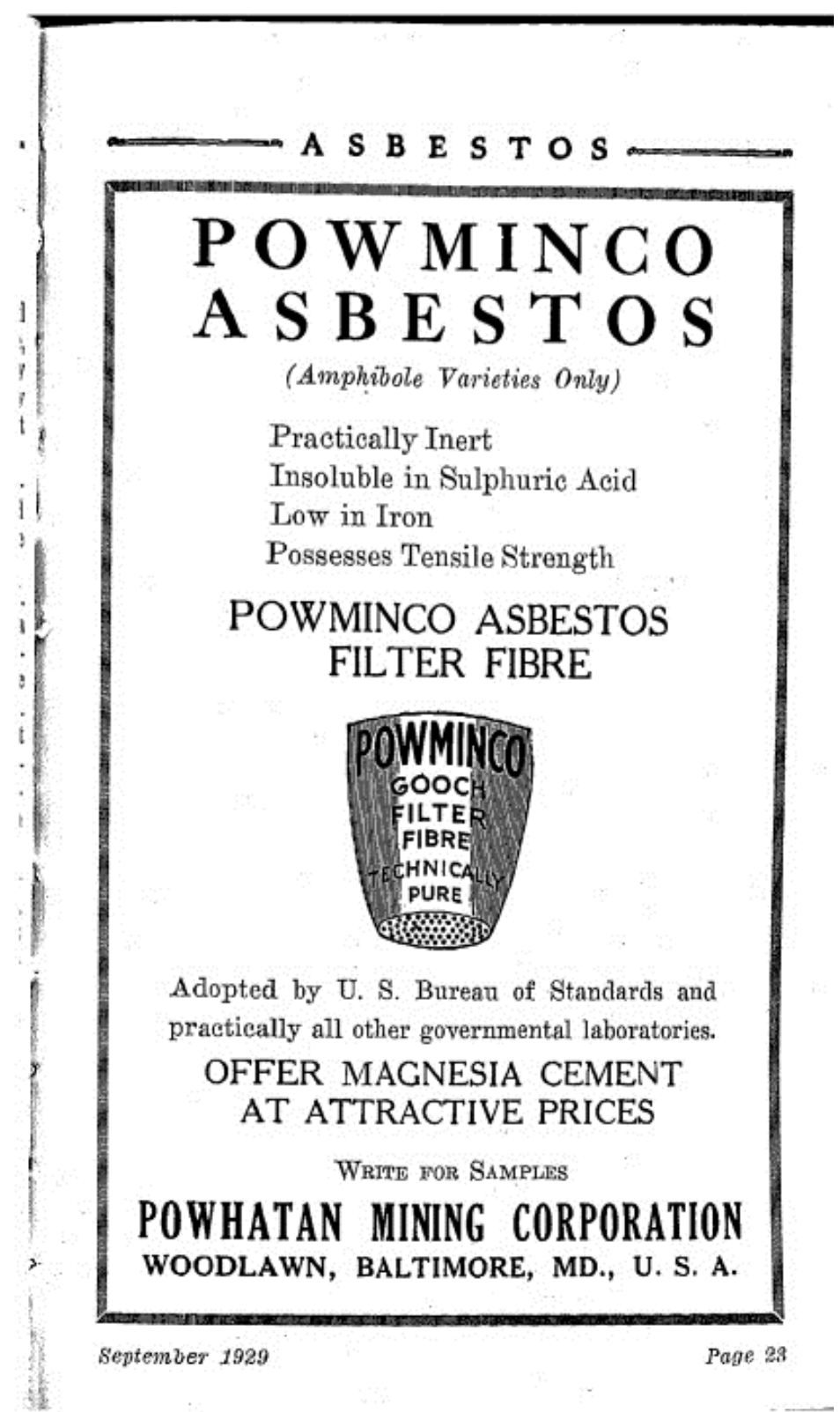

Figure 1.

Blake and colleagues took samples to determine the potential of these activities to release regulatory particles upon crushing and grinding. They said the concentration of anthophyllite, tremolite and cummingtonite asbestos was very low, most being cleavage fragment derived "fibers" of "little health consequence" (Blake et al., 1982). Nonetheless, development and building in the SSR area was extensive with considerable generation potential of amphibole "fiber". Nevertheless, a senior Georgia State Geologist (May, 2000 pers. comm.) said little was published in the papers and, it had been "amazingly quiet" presumably in terms of allegedly attributable asbestos disease claims.

The Sall Mountain Asbestos Company in northern Georgia was the first to mine anthophyllite asbestos in 
quantity in the United States (Avery et al., 1958). It was also possibly the first asbestos mine in the country (Avery et al., 1958) and largest producer of asbestos in Georgia (McCallie, 1910). The largest quantities from deposits on or near Sall Mountain were mined with some interruptions from 1894 until the 1970s (Frederick EPA $\mathrm{IV}^{11}$ ). Between 90 to 95 percent of the rock quarried was fiber (Geo. Geol. Survey $(1956)^{\mathbf{1 2}}$. The best asbestos was found near the surface where weathering made it soft and flexible (Geo. Geol. Survey (1956) ${ }^{13}$ (also see 'Weathering' below). These discoveries encouraged prospecting elsewhere and by the early 1900's, many other States reported deposits of anthophyllite asbestos (Avery et al.1958). Some believe the deposit at Sall Mountain was actually composed of three different sites in which the geo-mineralogy varied from site to site ${ }^{14}$ (Turner Reg IV 18 Nov 13, pers. comm.). Some said both tremolite and anthophyllite was found in one or more of these sites whilst others believe there was only anthophyllite (Turner Reg IV 18 Nov 13, pers comm.).

As the strategic importa.nce of many asbestos products soon became apparent, domestic asbestos production was greatly exceeded by domestic use (Avery et al., 1958). This, in turn, caused an increased need for asbestos as the reserves in asbestos-producing regions became depleted. The Georgia Geological Survey and the Surveys of many other States therefore initiated far-ranging programs to find new asbestos mines, occurrences, and areas geologically favorable for asbestos not only in the United States (including Alaska) but in Canada as well (Geo. Geol. Survey $(1956)^{15}$. At one point, Georgia became the most consistent producer of amphibole asbestos of any State (Geo. Geol. Survey (1956), Northern Georgia alone containing 17 former asbestos mines and 26 historic prospects (http://www.asbestos.com/states/georgia/).

Frederick EPA IV (18 Nov 13) ${ }^{16}$ said the mine and mill were based in Cleveland, Georgia, across the street from each other in White county. Frederick was not aware of any epidemiology, did not know how many people worked in the operations; was not aware of any company doctors; and did not know of any alleged mesothelioma clusters. O'Conner (12 May $00^{17}$ ) said many workers from the Sall Mountain Asbestos company lived in Cleveland and Gainesville, Georgia. The Geo. Geol. Survey (1956) ${ }^{18}$ said the fiber was milled in Gainesville about 27 miles from the mines. The mills apparently operated from 1894 to the 1970. In the early 1900 s, there were more than 100 workers at any one time ${ }^{19}$. Historical exposure conditions were probably very severe but no industrial data have been found. After consultation with different governmental agencies, there would appear to be, thus far, little available information concerning the workforce in the mine or the mill despite the fact that the operations ceased in the early 1970s, after nearly 80 years of work. A Sall Mountain EPA Site Assessment ${ }^{20}$ was done but this did not appear to yield such information.

Uses: The use of anthophyllite was limited by its lack of strength making it, with a few exceptions, too weak for spinning. It could not be used for asbestos-cement shingles or other products requiring the high tensile strength imparted by strong fibers. However, because of its superior resistance to acids, it was well suited for use in chemical laboratories, the stronger grades of anthophyllite being used for chemical filters (e.g. Avery et al., 1958). The Sall Mountain Asbestos Company manufactured rubber and mica roofing; fire-proofing materials; plastic cements to cover boilers, pipes and furnaces; filler in rubber, battery boxes, and molded electric insulation products; welding-rod coatings; paints; cement and plastic flooring; acoustical wall plasters; and stucco (Bowles, 1955, p. 14).

\subsection{North Carolina:Mining, Milling and Health Related Information}

Anthophyllite is the only asbestiform mineral found in North Carolina occurring in sufficient quantity and quality to be considered an asbestos ore (Conrad et al., 1963). Tremolite and actinolite are also very commonly associated with ultramafic rocks, but they occur in very limited amounts and most often in non-fibrous form (Conrad et al., 1963). Van Gosen (2007) lists no less than 41 anthophyllite occurrences in North Carolina of which 34 were past producers. The Powhatan Mining Company of Baltimore, Maryland was the most consistent and largest producer of anthophyllite asbestos in North Carolina and mined asbestos in North Carolina more or less continuously since 1918

\footnotetext{
${ }^{11}$ Discussions with Tim Frederick (404 562 8598) - 18 Nov 13. Frederick.tim@epa.gov

${ }^{12}$ GEORGIA GEOLOGICAL SURVEY VOL. IX NO. SPRING 1956

${ }^{13}$ GEORGIA GEOLOGICAL SURVEY VOL. IX NO. SPRING 1956

${ }^{14}$ pers com. Nardina Turner Reg IV Analytical Lab - 18 Nov 13. Turner.nardina@epa.gov 5628650

${ }^{15}$ GEORGIA GEOLOGICAL SURVEY VOL. IX NO. SPRING 1956

${ }^{16}$ Discussions with Tim Frederick (404 562 8598)- 18 Nov 13. Frederick.tim@epa.gov

${ }^{17}$ Discussions with Dr. Bruce O’Conner, Georgia State Geology, Georgia (404 6578379 fax / 656 3214) - 12 May 00

${ }^{18}$ GEORGIA GEOLOGICAL SURVEY VOL. IX NO. SPRING 1956

${ }^{19}$ In 1912, Sall Mountain Asbestos Company had 105 employees

${ }^{20}$ Donna Seadler. site assessment contact for Georgia, Sall Mountain. 404-562-8870. seadler.donna@epa.gov
} 
(Fred A. Mett, personal communication op cit. Conrad et al.,, 1963). All of the ore was shipped to the company's processing plant at Baltimore, Maryland. The only other major producer was apparently the Blue Rock mine discussed below. According to Conrad et al., (1963), the large tonnage mines were Kilpatrick, Asbestos, Newdale, Alders and Peterman through Powhatan and Blue Rock through the company with same name. No health-related information for any of these mines could be found. All of the ore from these and most other North Carolina deposits, except for Blue Rock, were processed in Baltimore by Powhatan.

All of the individual mines and prospects of North Carolina are listed in Van Gosen (2005). Deposits yielded up to several thousand tons of ore from mines in practically all of the counties in which the peridotites occurred. The Hippey mine in Yancey County, North Carolina also stockpiled anthophyllite asbestos until 1978. (Van Gosen, 2007). As in the other states already mentioned, the ore near the surface exposed to weathering was selected as it was quite soft and readily dug with a pick or dragline. To date, we have no industrial hygiene or epidemiological information regarding any of these operations. Conrad et al., (1963) said "Past production from North Carolina was mostly from mass-fiber deposits of the peripheral zone type. However, mass-fiber deposits of the anthophyllite-enstatite variety appear to have considerable potential." Historically, "whilst the first recorded attempt to mine asbestos in North Carolina was about 1901 and was reported to be chrysotile (Pratt, 1902, p. 98), the operation lasted only a short time and no production was recorded. From about 1910 until about 1925 considerable prospecting for amphibole asbestos was carried out and a number of favorable prospects were located. By 1919, North Carolina ranked third nationally in the production of asbestos. All of this production came from one producer, N. C. Mc Falls and consisted entirely of anthophyllite asbestos (Drane and Stuckey, 1925, p. 34). In 1925, the National Asbestos Company built a plant at Minneapolis, Avery County, to process anthophyllite asbestos ore from the Frank deposit. This mine and mill operated on a small scale until the late 1930s. Another plant was built at Norton, Macon County, at about the same time as the one at Minneapolis. However, if it ever processed any ore it was only a very limited amount. Between 1930 and 1947 a number of mining companies and individuals mined small to moderate amounts of anthophyllite asbestos. From 1941 to 1945, W. T. Hippey mined several thousand tons of ore from the Hippey mine. About 1941, the Industrial Minerals Corporation began mining at the Blue Rock mine and for several years produced relatively large tonnages of high grade mass-fiber anthophyllite asbestos which was processed at the company's mill at Spruce Pine. The Blue Rock mine was later controlled by the Mining and Milling Corporation of America and production was reported for 1953 and 1954. As of 1963, the Blue Rock mine was worked intermittently for several years but, as noted above, the largest producer of anthophyllite was the Powhatan Mining Company of Baltimore, Maryland. Production consisted mainly of the peripheral zone type of high-grade, mass-fiber ore. Deposits that yielded from considerably less than a hundred to several thousand tons of ore had been prospected and mined in practically all of the counties in which the peridotites occurred. Conrad et al. (1963) said that 16 mines had "recently been mined by Powhatan though only six of these were large tonnage, high quality ore mostly of the mass fiber peripheral type. Talc was often associated with the finely fibrous anthophyllite in several of these and tremolite found in at least one."

Because of the size, shape and occurrence of the deposits, all of the asbestos in North Carolina was mined by relatively simple open cut methods. In many instances, the ore was recovered entirely by hand labour using picks, shovels and wheelbarrows. More recent mining operations utilize bulldozers, front-end loaders, draglines and pneumatic drilling equipment. As of 1963, "most of the ore mined was of the peripheral zone type of mass-fiber asbestos. Pits developed in this type of ore followed the contact zone between the ultramafic body and the country rock and were therefore irregular in shape. Ore near the surface exposed to weathering was quite soft and readily dug with a pick or dragline. As the pit deepened, the ore became fresh, massive rock that had to be broken by explosives. ${ }^{21}$

Open pit mines developed in the peripheral zone deposits were limited in depth. As the pit was deepened the peripheral zone began to dip underneath the ultramafic body and timbering became necessary in order to keep the pit open. Also, the schistose contact zone was quite unstable which made for hazardous working conditions. Therefore, the development of the pit was again usually limited to the depth at which a dragline could effectively operate22. Conrad et al., 1963

Conrad et al., 1963 conservatively estimated that total past production of high grade, anthophyllite asbestos was

\footnotetext{
${ }^{21}$ When this became necessary, the drilling was done with pneumatic hand drills and dynamite was used to charge the holes. The mass-fiber ore was not hard, but exceedingly tough. Blasting was not very effective. Secondary breakage was often necessary and this was usually done with sledge hammers or dynamite. The open pit mines developed in the peripheral zone deposits were limited in depth to which a dragline could effectively operate.

${ }^{22}$ The hard or mass-fiber ore associated with the enstatolite bodies was mined by standard bench type quarry methods. This type of ore differed from the others in that much if not all of the body could be utilized as ore and the mining did not have to be as selective. This allowed larger amounts of ore to be mined by more efficient methods. Conrad et al., 1963
} 
at least 100,000 tons though owing to the nature of the deposits it was virtually impossible to make a reasonable estimate of the total reserves of anthophyllite asbestos in North Carolina. However, based on observations made during their investigation, it appeared that there was a minimum of 100,000 tons of asbestos in sight. This included only the hard mass-fiber ore associated with the enstatolite. Reserves of peripheral zone mass-fiber ore and cross- and slip-fiber ore were unknown.

The ore was treated by stage grinding, screening, and aspirating (shown in Figure 10 of Conrad et al., 1963). This type of process favored recovery of long anthophyllite fibers, which are important in some end uses. The results of dry processing are listed in Tables 1, 2 and 3 of Co Conrad et al., 1963nrad et al., (1963), and the mineral percentages were obtained by particle count. The distribution and composition of products from dry processing of nine samples are given in tables 1,2 , and 3 (ibid). These are particularly illuminating since talc made up, relative to the anthophyllite, a significant percentage of the fines. Conrad et al. (1963) also discussed acid leaching and wet processing. They concluded 23 that: "The type of flowsheet and extent of treatment are, of course, determined by the final product specifications. In the case of an anthophyllite, a talc, or talc-anthophyllite product, such properties as color, acid resistance, dielectric strength, thermal resistance, and high surface area should be capitalized on in the end-use, to insure proper and profitable utilization of the deposits."

\subsubsection{Origin of Anthophyllite asbestos in North Carolina}

Conrad et al. (1963) said that "In discussing the origin of the North Carolina anthophyllite asbestos deposits, two aspects of the problem have to be considered. First, is the origin of the amphibole mineral (anthophyllite), and second is the development of the fibrous or asbestos form." Their views reinforce the unique nature of anthophyllite asbestos in both instances. Thus, "In the case of the origin of the amphibole mineral, it may be stated that anthophyllite is not the result of original crystallization but has developed from secondary processes." This is not the case with the monoclinic amphibole asbestos fibers particularly since "This type of amphibolization has evidently resulted in the development of the peripheral zone type of mass-fiber asbestos" (Conrad et al., 1963). This is the primary type of formation from which most of the anthophyllite asbestos in North Carolina has been mined which is not the case for the monoclinic minerals.

Further morphogenetic similarities between Finnish and North Carolina Anthophyllite asbestos include regional metamorphism and igneous activity 24 as well as strong evidence for a hydrothermal origin for both (Conrad et al., 196325; Säntii et al., 2006).

\subsubsection{Weathering and Fibrosity in North Carolina}

Conrad et al. (1963) believed the development of "the fibrous or asbestos form of anthophyllite is largely a physical phenomenon directly related to weathering". They cite Hopkins' $(1914$, p. 106) explanation for fibrosity (albeit in Georgia) thus: "the fibrous form of amphibole is mainly the result of inherent abnormal development of prismatic cleavage (which) becomes more pronounced on weathering". Hopkins' actual explanation was: "What, then, causes the fibrous form in the case of mass- and cross-fiber anthophyllite? This question has never been satisfactorily answered, but the author, as the result of both megascopic and microscopic study of much of the material from Georgia, suggests the following as a partial explanation: Since the fibrous form of amphibole may be satisfactorily explained as the result of the abnormal development of the prismatic cleavage, that this cleavage was developed at the time of the formation of the mineral, and that the cleavage was made more pronounced through the agency of weathering. In other words, that the formation of abnormal cleavage is a crystallization phenomenon, for which no explanation is offered, while its commercial opening up is due, in part at least, to weathering agencies. These considerations bring up the subject of the depth of the deposits of amphibole asbestos. It has appeared almost universally that the asbestos rock would give place to less fibrous material at depths and finally to material that was not fibrous. This condition, if it is true, could readily be accounted for by the theory just advanced, that weathering is an essential part of the process of developing amphibole asbestos."

\footnotetext{
${ }^{23}$ Thus, "Acid leaching improved the color, acid resistance and dielectric strength of Anthophyllite and talc products. If the end-product is to be one in which the final color, dielectric strength, or acid resistance is important, and leaching is therefore necessary, then thought should be given to a more extensive wet process. A wet process has the following advantages over the screen-aspiration process previously described: (1) It is more efficient in the finer sizes; (2) Extreme fines may be 1effectively removed by dispersion and de-sliming; (3) Cleaner separation of talc from anthophyllite can be accomplished. (4) Whiter products are obtained. However, a wet process entails high drying costs and may not have merit unless leaching is necessary."

${ }^{24}$ Thus, "field relationships and limited laboratory work substantiate the fact that Anthophyllite was not an original mineral constituent of the ultramafic rocks but was formed by secondary processes. The ultramafic rocks in North Carolina have been subjected to one or more periods of regional metamorphism and, in many instances, to igneous activity." (Conrad et al., 1963)

${ }^{25}$ Suggested by: "the intimate relationship between some of the asbestos deposits and pegmatite dikes, quartz veins, corundum, chlorite, vermiculite and tourmaline" (Neathery, 1968)
} 
Conrad et al. (1963) go further saying "That a direct relationship exists between degree of fiberization and extent of weathering is also quite apparent in the asbestos deposits in North Carolina. This is particularly true in the peripheral zone mass-fiber deposits and the anthophyllite-enstatite mass-fiber deposits. In fact, it is common practice to allow ore mined from some of these mass-fiber deposits to remain in a stockpile exposed to the elements for a year or more. This is reported to soften the ore considerably, which results in easier milling and increased fiber length recovery". The relationship between fiber recovery, peripheral mass fiber formation and weathering is also clear from the following: "The mass-fiber asbestos associated with the peripheral zone varies in color from grayish white to various shades of mottled buff and light-brown. Ore that lies on and near the surface is usually badly stained by iron oxide and quite soft. The deeper ore is more compact, but the fibers can be easily separated by hand. Much of the mass-fiber ore is very coarsely crystalline material composed of interlocking bundles of fibers that are as much as 2 to 3 inches in length. Other mass-fiber ore is less coarsely crystalline and, in some deposits the fibers are arranged in distinct radial form.... The peripheral zones of mass-fiber ore are composed predominantly of asbestos. Anthophyllite usually makes up more than 85 percent of the rock and talc is the only other mineral present in significant amounts. ... Because of the high percentage of asbestos present in the mass-fiber deposits, the high ratio of ore recovery to total amount of rock mined, and the relatively simple mining methods employed, most of the past production of North Carolina asbestos has come from peripheral zone mass fiber deposits."

Further discussion of weathering relates to the dunites from which anthophyllite is often derived for as Conrad et al. (1963) said: "the most important variety of periodotite in North Carolina and the largest bodies of periodite are dunites" being "composed almost entirely of olivine". These are "quite susceptible to alteration and weathering". Thus, the periodites "consist mainly of olivine, but may contain varying amounts of other mafic minerals such as amphiboles, pyroxenes, and in some cases mica. The peridotites in North Carolina vary considerably in mineralogical composition, both within individual deposits and from one deposit to another."26 The alteration of olivine to anthophyllite involves the loss of magnesium and iron or the addition of silicia, whereas the alteration of enstatite to anthophyllite is a physical transformation as the two minerals have essentially the same chemical composition. Amphibolization is a late stage process that took place after the individual peridotite bodies were emplaced in their present relative positions and after any crushing or granulation effects. This is demonstrated by the fact that the amphibole crystals are oriented in all directions with respect to each other and, except for cross fracturing, are not disturbed. The release of iron during amphibolitization and fibrous crystal formation may account for the brown discoloration noted during weathering ${ }^{27}$.

\subsubsection{Chromite and the Origin of Anthophyllite asbestos in North Carolina and Finland}

Chromite is the most common primary mineral in dunites and is characteristic of all the peridotites throughout the region28. Säntii et al., (2006) used chromite to identify key features of areas in which the Finnish anthophyllite formed. Chromite was called an important petro-tectonic indicator in the only primary igneous phase identified in their study of the Outokumpu - Jormua ophiolitic belt. The latter was thought to contain the oldest documented examples of exhumed mantle lithosphere. This contained protolith periodites that eventually gave rise to olivine - talc - anthophyllite - enstatite - bearing periodites. Säntii et al., (2006) also emphasized the Precambrian origin of the deposits and their syntectonic hydrothermal origin.

We could find no health-related information concerning the mining activities of anthophyllite asbestos in North Carolina.

\footnotetext{
${ }^{26}$ The development of amphibole is very common in the ultramafic rocks in North Carolina. In the dunites minute needle-like crystals of amphibole (usually anthophyllite) occur disseminated throughout the mass. The needles are usually straight, oriented in all directions, and penetrate several individual olivine grains. An increase of the amphibole needles in both size and number ultimately leads to the local development of zones composed almost entirely of crossed and interlocking amphibole minerals. The alteration to amphibole is particularly evident in the enstatolites. Where enstatite is present in the rocks, the needles of amphibole may penetrate the enstatite in all directions or develop parallel to the long dimension of the enstatite crystals. In either case, this type of alteration has evidently resulted in the formation of some of the mass-fiber asbestos deposits.

${ }^{27}$ Anthophyllite is the fibrous form of the orthorhombic amphibole anthophyllite. ... Un-weathered anthophyllite is greenish-gray to gray, but upon weathering the fibers become brownish-white.

${ }^{28}$ History of NC Antho asbestos: North Carolina has been a small, but consistent producer of anthophyllite asbestos for many years. Although the peridotite bodies with which the asbestos is associated have been studied at various times for other economic minerals, such as olivine, vermiculite, chromite, and corundum, there have been no systematic studies of asbestos. ... Subsequently, the peridotites received very little attention until the Tennessee Valley Authority began its study of regional products during the middle and late 1930s. Several reports dealing with economic minerals associated with the peridotites resulted from studies conducted by the Tennessee Valley Authority in cooperation with the North Carolina Division of Mineral Resources. The first of these was by Hunter (1941) on the fosterite olivine deposits. Others were by Hunter, Murdock and MacCarthy (1942) on the chromite deposits and by Murdock and Hunter (1946) on the vermiculite deposits.
} 


\subsection{Alabama}

\subsubsection{Mining, Milling and Health Related Information}

The Geological Survey of Alabama in concert with the US Bureau of Mines under the direction of Neathery and his colleagues $(1967,1968)$ undertook a detailed study of the formation, occurrence and mining of anthophyllite in Alabama which appears to be the "terminus" of the Appalachian - Ural Welt of ultramafic rocks through which anthophyllite forms, starting in Finland. Various features of their description also link Alabama to the Finnish deposits. They said "In view of the expanding market and anticipated growth of the asbestos industry, an appraisal of Alabama's anthophyllite and talc resources was considered necessary. Much of the anthophyllite was mined in the talc deposits in the Dadeville area of Tallapossa county first noted by Smith in 1873 in prospects opened in search of corundum. This was similar to the situation in North Carolina noted above. Similarly, from 1939 to 1940, extensive prospecting for chromite also took place in the Dadeville area, chromite being another important feature of the North Carolina deposits. Various companies explored these areas (Red Hawk Mining Co., Montgomery, Ala. In 1953; the American Talc Co., Alpine, Ala. and the Tallapoosa Mining Co., Camp Hill, Ala In 1963; Black Warrior Petroleum Co., 1965). Powhatan Mining Co., Baltimore, Md had the largest holding in 1965 and conducted extensive exploration activities on the property, excavating numerous pits and trenches, shipping several carloads of crude material from 1966-67 from Dadeville for test purposes. Unfortunately, the overall yields from the Alabama deposits were relatively small and none of the deposits were mined after 1967. Nonetheless, there would have appeared to have been extensive potential for environmental exposure for whilst "the exposures of amphibolite were few even though the amphibolite zones were extensive and numerous with outcrops often exceeding 6 miles in length varying in width from 100 feet to over a mile". The most significant deposits of anthophyllite were found in the eastern part of the county near Dudleyville.

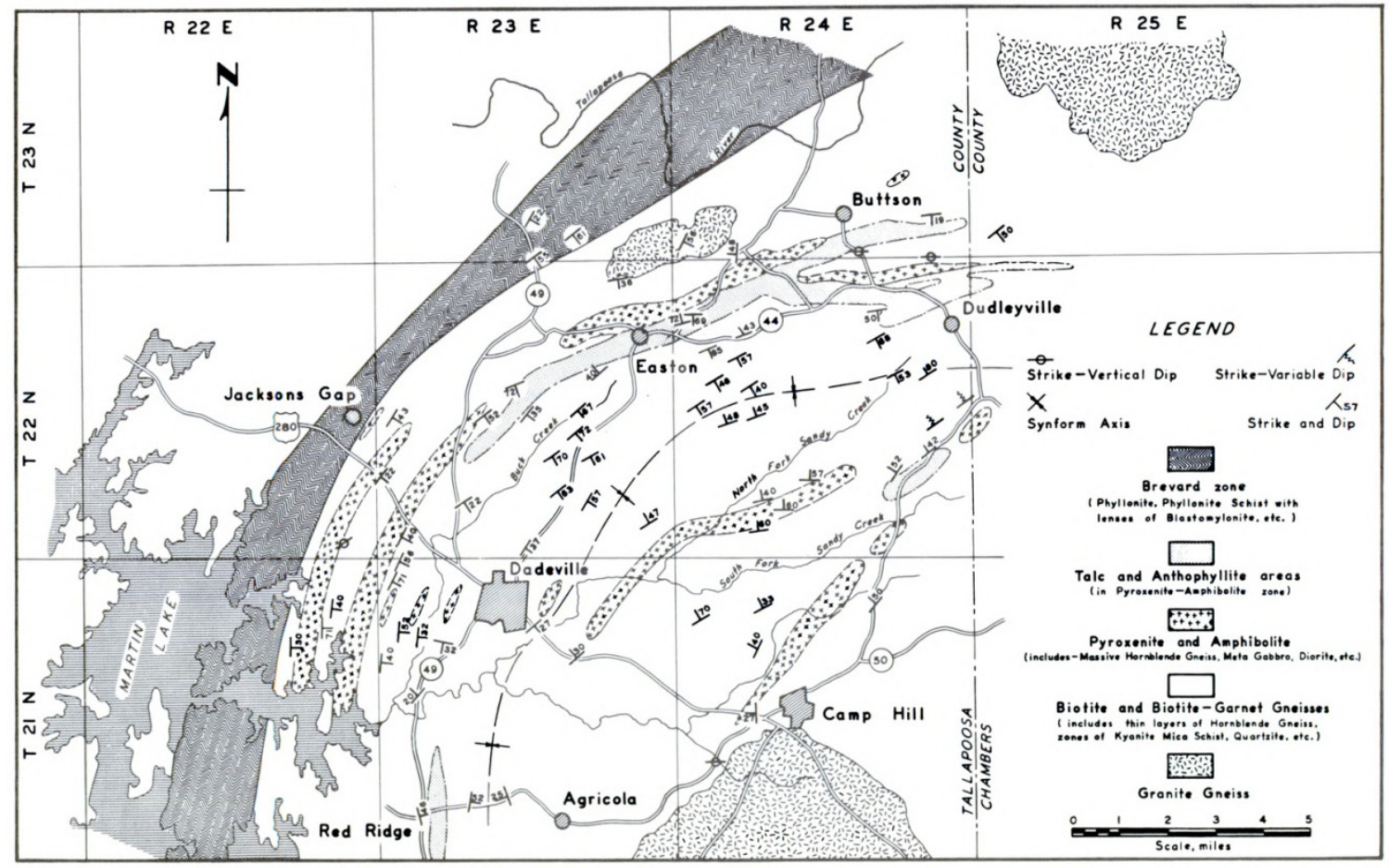

Figure 2. Geologic rock-type map of the Dadeville area. ex. Neathery et al., 1967

From fig 2 (Neathery et al. (1967), one can see the proximity of the anthophyllite deposits to a number of towns in the area and thus the potential for environmental exposure but we have no health-related information for this or any related to other small mining activities conducted at this time.

\subsubsection{Weathering and Origination}

Neathery (1968) said "The development of fibrous asbestiform anthophyllite has been considered to be partly related to physical phenomena directly related to weathering. The softest and most fibrous anthophyllite in the Dadeville area occurs generally near the weathered surface of the deposit, and, with increasing depth, the 
anthophyllite fiber is harder, more brittle, and less easily worked. The anthophyllite asbestos in Alabama was said to be greenish gray to gray in fresh un-weathered specimens but weathered to a characteristic clove brown. Neathery (1968) also noted "The alteration of olivine to anthophyllite (that) involved the elimination of a part of the magnesium and iron" release of the latter potentially contributing (as was noted in North Carolina and Georgia) to the brownish discoloration of the weathered fiber.

Hodgson (1986) thought anthophyllite formation in Alabama was particularly interesting and said it was due to "secondary mineralization and tensional stress" arising uncommonly in "vein deposits" such as those seen in Tallapoosa and Chambers counties. In addition, the Alabama deposits are also found as massive peripheral depositions such as those noted prominently in North Carolina and Georgia. Thus, "The most common form of anthophyllite in the massive asbestos is that in which the anthophyllite fiber has developed parallel to the long direction of the enstatite crystal whereas a less common form not readily observed in Alabama is the variety of mass-fiber anthophyllite in which the fibers occur as a mass of interlocking cones". In Alabama, in comparison to North Carolina, cross fiber was more common with the fibers arranged parallel to each other and perpendicular to the walls of the vein" that may vary from a fraction of an inch up to 12 to 14 . inches in width, but average 1 to 4 inches." The apparent relative shift to 'linear' vein-like from radial massive formation is particularly curious and requires additional study. What role, if any, the abundance of talc might have is not clear. However, electron micrographs (for example fig. 12 from Neathery, (1968)) show the highly fibrous characteristics of anthophyllite, in this case in a sample from the Dadeville area in Alabama.

However, in contrast to Hopkins (1914) cited by Conrad et al. (1963) regarding the proposal that weathering is an integral part of amphibole fibrosity (see: 3.3.2 Weathering and Fibrosity under North Carolina), Säntii (pers comm, 2018) said 'fibrous amphiboles are formed and crystalized by metamorphic processes, not by weathering. It is possible that weathering (softening) makes quarrying easier; because fiber bundles are by weathering more easily split apart. But the asbestos formation is originally metamorphic - hydrothermal, not weathering".

The methods used to mine (to the extent very small, amounts were indeed mined) anthophyllite in Alabama were very similar to those used in North Carolina and Georgia. Thus, "Simple mining methods were employed in the extraction and recovery of anthophyllite asbestos because of the size, shape, and occurrence of the deposits. Open-cut methods were generally used. In many instances, the ore was recovered entirely by hand labor using picks, shovels, and wheelbarrows. Auxiliary equipment may include bulldozers, front-end loaders, draglines, and pneumatic drilling equipment". Most of the anthophyllite mined to date in Alabama had been from shallow deposits. Both vein and mass-fiber material have been recovered. (Due to weathering), the "Ore near the surface was usually quite soft and could be removed by hand methods. With depth, the anthophyllite became harder and more compact and hammers and dynamite were employed to break up the larger masses"(Neathery, 1968).

\subsubsection{Talc in Alabama}

"The occurrence of talc (in Alabama) appeared to be far greater than the available anthophyllite. The total potential talc-anthophyllite-bearing zone of the Dadeville amphibolite belt may encompass as much as 6,800 acres of timberland and farmland. Based on field observations, it is possible that 25 percent or 1,700 acres of the land could contain talc or talcose material. ... Calculations, based on evaluation of three talc samples and five significant talc-bearing properties, indicate the potential availability of approximately 8 million tons of talc. Considerable tonnages of anthophyllite asbestos could conceivably be derived as a primary product or as a secondary product from talc mining. The associated talc deposits, although somewhat inferior in grade to other talc deposits of the eastern United States, occur in significant quantities to be considered a primary resource." (Neathery, 1968)

\subsubsection{Other US States}

Numerous anthophyllite deposits are found in other States in the Eastern and Western parts of the United States (Van Gosen, 2007, 2008). However, fewer were ever actively mined and indeed to a much lesser extent than Maryland, Georgia and North Carolina. In the East Coast, Pennsylvania has 22 potential anthophyllite occurrences 18 of which were mined some being very near to areas of habitation. Virginia had one past producing mine. New York has anthophyllite as a non-asbestiform contaminant of its Gouvenor talc that is formed from dolomitic marble. Maine had a major anthophyllite deposit that uniquely also produced a few million pounds of copper from Corderite. Anthophyllite was mined from Pelham granite in Massachusetts and a Vermont anthophyllite quarry was the site of a unique form of anthophyllite described in detail by Veblen \& Burnham (1978) in their pioneering studies of amphibole microstructures to be described in the final part of this series.

In the West, Colorado had one anthophyllite occurrence in a uranium mine. Idaho had an anthophyllite asbestos mine at Orofino that used material as fillers for millboard, plasters, cements, and paints. Another, near Klamaith, 
that produced anthophyllite that was used in pipe and boiler covers, wall plaster and paint, and as a binding agent cements and asphalts since 1909. Montana had the Karst mine that produced anthophyllite asbestos fiber used as insulation at oil refineries, in asphalt roofing compound, and in the manufacture of wall and ceiling insulation

\section{Health Issues}

\subsection{Epidemiology of Mesothelioma due to American Anthophyllite}

From the aforementioned discussion, it is likely that thousands of people were "occupationally", "para-occupationally" and "environmentally" exposed to anthophyllite asbestos and innumerable others exposed to many diverse American anthophyllite based products during their historical production and/or use. Nonetheless, we have not found any reports of an attendant mesothelioma response from such exposures. One might argue most of these mining activities were too old for evaluation. However, domestic exposures to children borne to miners and residents who lived nearby the mining and manufacturing operations after 1950 may have had the potential to demonstrate an attributable mesothelioma response after 1960 when the association with asbestos was first confirmed with any level of diagnostic stability. Nonetheless, to date, none to our knowledge, has ever been demonstrated nor are we aware of any such claims related to the American anthophyllite industry.

\subsection{Endemic Pleural Plaques due to Naturally Occurring Anthophyllite Asbestos in the United States}

Many anthophyllite asbestos occurrences and mining sites exist near local populations and some major cities in the United States. However, zones of endemic pleural plaques similar to those found in Finland have not been reported. The soft nature of the weathered largely superficial naturally occurring deposits of anthophyllite asbestos which was preferentially mined, facilitated airborne release. Indeed, hundreds of naturally occurring deposits of anthophyllite asbestos are found across America but zones of endemic pleural plaques such as those seen in Finland (Ilgren \& Hoskins, 2018a) have not been reported. Since pleural plaques are readily detectable radiologically and are sufficiently characteristic to be distinguished from other nonspecific pleural lesions, if they were present in significant numbers, they would have been reported.

One explanation for the differences between the two countries may be differences in exposure scenarios between the United States and Finland. Thus, anthophyllite asbestos was extensively used domestically in many homes in Finland e.g. in Karelia for saunas, ovens, wall boards, which created significant indoor exposure. Construction and repair indoors particularly in a country with ten months of winter, could create exposures far and above those from the naturally occurring sources found near some American homes. The widespread presence of natural occurring anthophyllite asbestos however might produce pleural plaques in sheep or cows grazing on anthophyllite asbestos rich soils. Such studies would be interesting to conduct.

\section{Japan}

Whilst the geo-tectonic and geological relationship between the Japanese, Finnish and American anthophyllite deposits is not entirely clear, Hodgson (1986) noted the extensive deposition of anthophyllite asbestos in central Russia and surmised these may be contiguous with those in Japan.

\subsection{Geology}

Neathery (1968) said "The rocks of the Inner Piedmont of Alabama are similar to the metamorphic facies of the Abukuma-type series of regional metamorphism. It is assumed that the intercalated volcanics would also be products of high temperature, low pressure metamorphic environment". In Japan the Ryoke-Abukuma belt follows the southern coast of Honshu island and extends over a length of more than $1300 \mathrm{~km}$ (Winkler, (1967)) (Fig 3). At its southern extent, it crosses the smaller island Kyushu where there is an area known for its long term mining and milling of anthophyllite; Matsubase. It was at Matsubase near the town of Kumamoto where a large-scale open-cast asbestos mine and mill was in operation between 1883 and 1970 (Hiraoka, 1993, Hiraoka et al., 1998). 


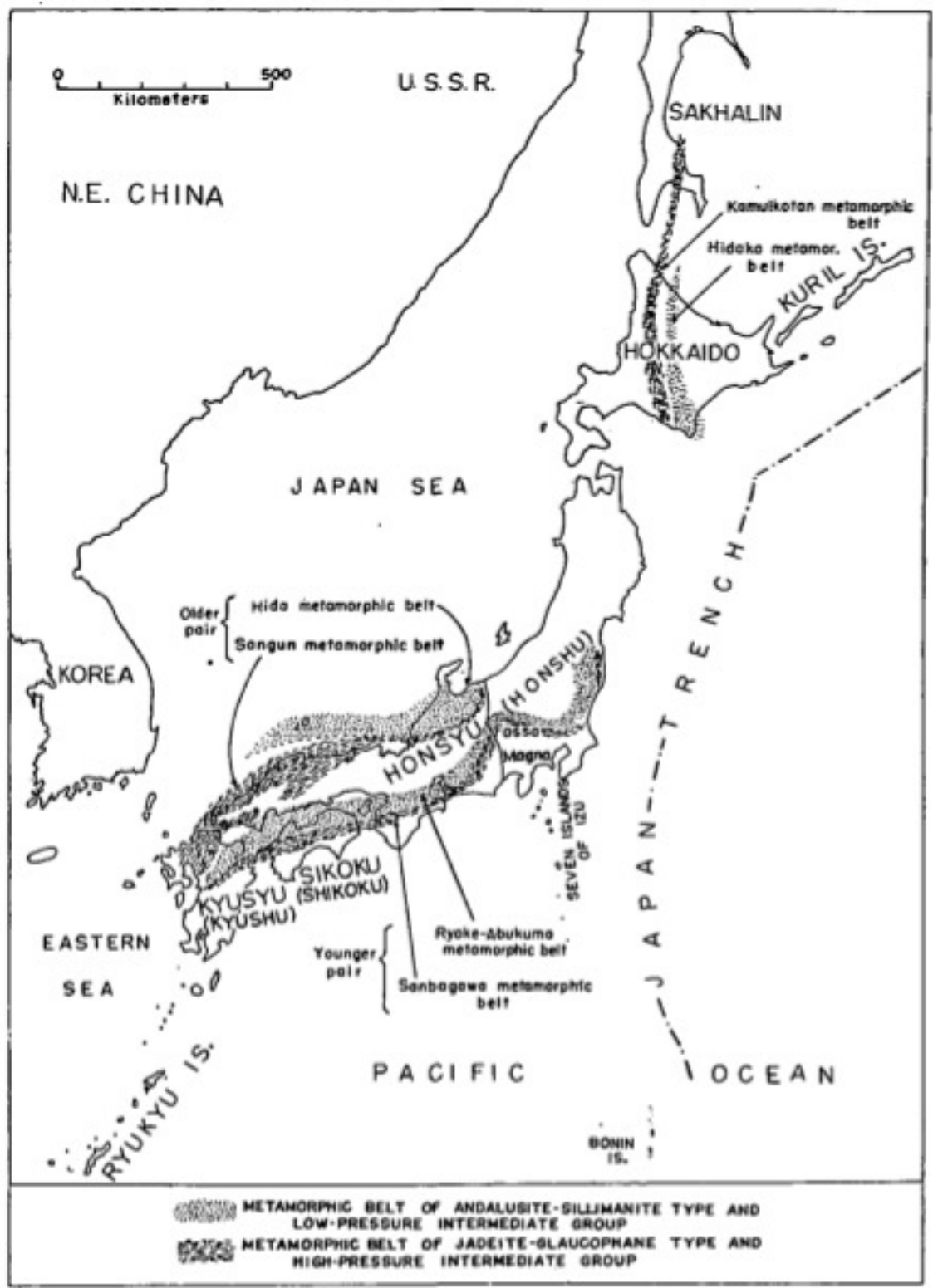

Figure 3. Metamorphic belts of Japan, restored to the original state

\section{Japan Health Issues}

\subsection{Mining, Milling and Health Related Information}

The large former open cast anthophyllite mine operated in Matsubase, a rural part of southern Japan from 1883 to 1935 on a small scale and then from 1935 to 1970 as a large operation (Murai, 1997; Murai et al., 1998). A special mass screening follow-up system was instituted for 5 years, from 1989 to 1993, to investigate the health of the inhabitants (Hiraoka, 1993, Hiraoka et al., 1998). There has been no evidence of malignant mesothelioma, during the last 17 years at the National Kumamoto Minami Hospital, the center for respiratory diseases servicing the Matsubase area. Many people in Japan were also "environmentally" exposed to anthophyllite asbestos in the areas around the mine site. They have never been shown to demonstrate a mesothelioma response, only a very significant excess in pleural plaques (Hiraoka, 1993, Hiraoka et al., 1998). The pleural plaques were found in 1357 persons (724 men and 633 women) among the inhabitants who were more than 20 years of age in Matsubase between 1988 and 1993 (Murai, 1997; Murai et al., 1998; Hiraoka et al., 1993). CT scans ascertained 938 cases with pleural plaques among the 1,114 persons who participated". At least $9.5 \%$ of the inhabitants over 20 years of age in this town had pleural plaques and in the town with the highest pleural plaques the figure was higher still (41.5\%) (Hiraoka, 1993, Hiraoka et al., 1998). "The fact that there is a high prevalence of pleural plaques but no evidence of mesothelioma is 
in accordance with the characteristics of anthophyllite asbestos exposure" (Hiraoka, 1993, Hiraoka et al., 1998). Air samples also revealed elevated airborne anthophyllite asbestos concentrations in the pleural plaque area (Hiraoka, 1993, Hiraoka et al., 1998). Lung burden studies of pleural plaque cases with no occupational exposure revealed elevated levels of anthophyllite fibers with mean diameters of $0.84 \mu \mathrm{m}$ that were much thicker than amosite or crocidolite leading the authors (Murai and Kitigawa, 1998) to say "Perhaps these differences in fiber size are related to the strength of the carcinogenicity to the pleura." Lung burden studies also demonstrated levels as high as 0.8 million $\mathrm{f} / \mathrm{gm}>5 \mu \mathrm{m}$ (Murai et al., 1997) and 18 million $\mathrm{f} / \mathrm{gm}>5 \mu \mathrm{m}$ of anthophyllite asbestos in residential pleural plaque cases in the Matsubase area.

Thousands of factory workers were exposed to anthophyllite asbestos fiber in Osaka, Kobe, and Tokyo that used the high-quality fiber whilst the low-grade fiber was sold to other Japanese factories to produce fire-resistant panels and small cooking stoves (Hiraoka, 1993, Hiraoka et al., 1998) and have never been shown to demonstrate an attendant mesothelioma response. Many family members of the factory workers were "para-occupationally" exposed to anthophyllite asbestos. Thousands of residents living around the factories environmentally exposed to anthophyllite asbestos have also, to our knowledge, never been shown to demonstrate an attendant mesothelioma response. Similarly, thousands of Japanese workers and consumers have been exposed to the anthophyllite asbestos based products produced in the Matsubase operation. They too, to our knowledge, have never been shown to demonstrate an attendant mesothelioma response.

\subsection{Lung Burden Data}

Since anthophyllite is a common form of 'non-commercial' amphibole found in many parts of the world, not just Finland, India, the United States and Japan it can account for a significant 'background' of anthophyllite fibers in the lungs of many individuals with no asbestos disease. Numerous natural non-commercial and commercial sources of anthophyllite together account for this background level not just the innumerable naturally occurring deposits of anthophyllite asbestos but also a variety of industrial and non-industrial products containing talc, vermiculite, corderite, and chrysotile both found naturally and in a multitude of commercial products. Anthophyllite lung burdens in excess of one million fibers per gram lung dry weight are found in some individuals with no evidence of asbestos related disease. Significantly higher levels, well above this level are generally believed to denote 'occupational' exposure (Karjalainen et al., 1994) (300 urban men); Karjalainen et al., 1993a (lobe of origin); Uibu et al., 2009; Karjalainen et al. 1993b. (occup hx); Tuomi 1992; Tuomi et al., 1989; Tossavainen et al., 1994; Vilkman et al., 1993). Large scale exposure to anthophyllite asbestos is represented in various lung burden studies of non-occupationally exposed individuals in Finland with no evidence of an attendant mesothelioma response with up to one million fibers per gram lung with, a significant percentage (e.g. $>25 \%$ if not greater) of fibers also being greater than $10 \mu \mathrm{m}$ in length (Karjalainen et al., 1994; Uibu et al., 2009; Tuomi et al., 1992). Gibbs and Pooley (1996) said "non-exposed controls uncommonly show combined amphibole levels of more than two million fibers per gram whilst most cases of mesothelioma exceed this". Large scale exposure to anthophyllite asbestos is represented in various lung burden studies of non-occupationally exposed individuals in the United States and Canada with up to one million fibers per gram lung with no evidence of an attendant mesothelioma response. This was so even though in some reports (Dodson et al., 1999) "the only asbestos fibers that met the Stanton criteria (length $>\mu \mathrm{m}$ and diameter $<0.25 \mu \mathrm{m}$ ) were the anthophyllite fibers" (also see Churg and Warnock, 1980). This further reinforces the notion that anthophyllite asbestos does not induce mesothelioma.

\section{Conclusions}

Large numbers of workers "occupationally" and "para-occupationally" exposed to anthophyllite asbestos in the United States and Japan have never been shown to demonstrate an attendant mesothelioma response. Anthophyllite is one of the most common forms of 'non-commercial' amphibole in the world and many thousands of people have been environmentally exposed to this form of asbestos. Numerous natural non-commercial and commercial sources of anthophyllite exist to account for this background level. This accounts for the significant 'background' of anthophyllite fibers in the lungs of many individuals with no asbestos disease. Consequently, anthophyllite lung burdens in excess of one million fibers per gram lung dry are found in some individuals with no evidence of asbestos related disease. Anthophyllite levels between one and four million are said to denote 'occupational' exposure. However, some non-exposed controls are known with combined amphibole levels of more than two million fibers per gram although most of the cases of mesothelioma are found to exceed this. The Finnish, American and Japanese experience with anthophyllite asbestos is in stark contrast to other forms of amphibole asbestos such as crocidolite from South Africa and Wittenoon where to date many tens of thousands of cases of mesothelioma have been reported. The major biological discriminating factor is fiber width and, to a lesser extent, durability. The origin of anthophyllite per se and its mode of fiberization appear to differ significantly from other forms of amphibole asbestos. Weathering appears to be common to the principle domestic sites of anthophyllite asbestos 
formation again differing from the other forms of amphibole asbestos. The final paper in this four-part series will examine the potential bases for the fundamental differences between the orthorhombic anthophyllite asbestos and monoclinic forms such as crocidolite.

\section{References}

Asbestos in Sweden. Retrieved from http://asbestosglobal.org/asbestos-in-sweden/

Aurola, E. (Ed.). (1954). The Mines and Quarries of Finland. Geological Survey of Finland. Geoteknillisiä julkaisuja, 55, 1-123.

Avery, R. B., Conant, M. L., \& Weissenborn, H. F. (1958). Selected Annotated Bibliography of Asbestos Resources in the United States and Canada. Geological Survey Bulletin 1019-L United States Government Printing office, Washington.

Bangs, H. (1946). Maryland. A Journal of Natural History, 16(4), 67-73.

Betts, J. H. (2009). The Minerals of New York City. Rocks and Minerals magazine, 84(3), 204-252. Retrieved from http://www.johnbetts-fineminerals.com/jhbnyc/articles/nycminerals1.htm

Blake, R. L. (1982). Amphiboles of the Soapstone Ridge, Ga, United States Depart U.S. Bur. Mines Bull. 552 ment of the Interior, Bureau of Mines, Report of Investigation $8627.17 \mathrm{pp}$.

Bowles, O. (1955). The asbestos industry: U.S. Bur. Mines Bull. 552, 122 p.

Chaumba, J. B., \& Murphy, B. (2013). The Soapstone Ridge Complex, Southern Appalachians: Petrographic, mineral compositional, and oxygen isotope investigation. Canadian Journal of Earth Sciences, 50(4), 423-438. https://doi.org/10.1139/cjes-2012-0112

Churg, A., \& Warnock, M. L. (1980). Asbestos Fibers in the General Population 1- 3. The American Review of Respiratory Disease, 122(5), 69-78. https://doi.org/10.1164/arrd.1980.122.5.669

Conrad, S. G., Wilson, W. F., Allen E. P., \& Wright, T. J. (1963). Anthophyllite asbestos in North Carolina. North Carolina Department of Conservation and Development, Division of Mineral Resources, Raleigh. Bulletin No. 77, 61p.

Dodson, R. F., Williams, M. G., Huang, J., \& Bruce, J. R. (1999). Tissue Burden of Asbestos in Nonoccupationally Exposed Individuals From East Texas. American Journal of Industrial medicine, $35(3)$,

281-286. https://doi.org/10.1002/(SICI)1097-0274(199903)35:3<281::AID-AJIM8>3.0.CO;2-O

Drane, B. S., \& Stuckey, J. L. (1925). The mineral industry in North Carolina from 1918 to 1923 (inclusive). Published: Raleigh, N.C. Geological and Economic Survey.

Gibbs, A. R., \& Pooley, F. D. (1996) Analysis and interpretation of inorganic mineral particles in "lung" tissues. NIOSH Occupational Lung Disease - 3. Thorax 51, 327-334. https://doi.org/10.1136/thx.51.3.327

Hiraoka, T. (1993). Endemic pleural plaques in the town of Kyushu, island of Japan. In G. Gibbs (Ed.), Health risks from exposure to mineral fibers: An International Perspective (pp. 242-246). New York, Ontario. Canada. Captus University Pub.

Hiraoka, T. et al. (1998). Anthophyllite exposure and endemic pleural plaques in Kumamoto, Japan. Scand $J$ Work Environ Health, 24(5), 392-397. https://doi.org/10.5271/sjweh.360

Hodgson, A. A. (1986). Scientific advances in asbestos, 1967 to 1985: Crowthorne, United Kingdom, Anjalena Publications Ltd., $186 \mathrm{p}$.

Hopkins, O. B. (1914). A report on the Asbestos, Talc and Soapstone deposits of Georgia. Bulletin No. 29.

Horton, T. (1970). Asbestos processor finds itself center of attention. The Baltimore Sun. 15 Sept 1977.

Hunter, C. E. (1941). Fosterite olivine deposits of North Carolina and Georgia: North Carolina Dept. Cons, and Devi. Bull. No. 41, 117 p.

Hunter, C. E., Murdock, T. G., \& MacCarthy, G. R. (1942). Chromite deposits of North Carolina: North Carolina Dept. Cons, and Devi. Bull. No. 42, 39 p.

Ilgren, E. B., \& Hoskins, J. A. (2018a). Anthophyllite Asbestos: The Role of Fiber Width in Mesothelioma Induction Part 1: Epidemiological Studies of Finnish Anthophyllite Asbestos. Environment and Pollution, 7(1), 9-23. https://doi.org/10.5539/ep.v7n1p9

Ilgren, E. B., \& Hoskins, J. A. (2018b). Anthophyllite Asbestos: The Role of Fiber Width in Mesothelioma 
Induction Part 2: Further epidemiological studies of occupational, domestic and environmental exposure to Finnish Anthophyllite asbestos. Environment and Pollution, 7(1), 24-35. https://doi.org/10.5539/ep.v7n1p24

Karajalainen, A., Anttila, S., Heikkila, L., Kyyronen, P., \& Vainio, H. (1993a). Lobe of origin of lung cancer among asbestos-exposed patients with or without diffuse interstitial fibrosis. Scand J Work Environ Health, 19(2), 102-107. https://doi.org/10.5271/sjweh.1490

Karjalainen, A. et al. (1994). Asbestos exposure and pulmonary fiber concentrations of 300 Finnish urban men. Scand J Work Environ Health, 20(1), 34-41. https://doi.org/10.5271/sjweh.1431

Karjalainen, A., Anttila, S., Heikkila, L., Karhunen, P., Vainio, H. (1993b). Asbestos exposure among Finnish lung cancer patients: Occupational history and fiber concentration in lung tissue. American Journal of Industrial Medicine, 23, 461- 471. https://doi.org/10.1002/ajim.4700230309

King, J. A. (1957). The petrography and structure of a portion of Soapstone Ridge, DeKalb and Clayton Counties, Georgia: (M.S. thesis) Atlanta, Emory University, 34 p.

King, L. C. (1967). Morphology of the Earth (2nd ed.). London, Oliver \& Boyd.

King, P. B. (1955). A geologic section across the southern Appalachians: an outline of the geology in the segment in Tennessee, North Carolina, and South Carolina. In R. J. Russell (Ed.), Guides to southeastern geology: Geological Society of America (pp. 332-373).

Lindgren, W. (1925). The cordierite-anthophyllite mineralization at Blue hill, Maine, and its relation to similar occurrences. Proc. Nat. Acad. Sci., 11(1). 1-4. https://doi.org/10.1073/pnas.11.1.1

McCallie, S.W., (1910). A preliminary report on the mineral resources of Georgia: Geological Survey of Georgia Bulletin No. 23, p. 33-36.

Meurman, L. O., Pukkala, E., \& Hakama, M. (1994). Incidence of cancer among anthophyllite asbestos miners in Finland. Occup Environ Med, 51, 421-425. https://doi.org/10.1136/oem.51.6.421

Morgan, B. A. (1977). "The Baltimore Complex”, Maryland, Pennsylvania and Virginia. Paper in North American Ophiolites. In R. G. Coleman, \& W. P. Irwin (Eds.), State of Oregon, Dept. of Geology and Mineral Industries (pp. 41-49). Bull. 95.

Murai,Y., Kitagawa, M., \& Hiraoka, T. (1997). Fiber analysis in lungs of residents in a Japanese town with endemic pleural plaques. Archives of Environmental Health, An International Journal, 52(4), 263-269. https://doi.org/10.1080/00039899709602196

Murdock, T. G., \& Hunter, C. E. (1946). The vermiculite deposits of North Carolina: North Carolina Department of Conservation and Development, Division of Mineral Resources, Bulletin No. 50, 44p.

Neathery, T. L. (1968). Talc and anthophyllite asbestos deposits in Tallapoosa and Chambers Counties, Alabama: Alabama: Geological Survey of Alabama Bulletin 90, 98 p.

Neathery, T. L., LeVan, H. P., Ahrenholz, H. W., \& O’Neill, J. F. (1967). Talc and asbestos at Dadeville, Ala.: U.S. Bureau of Mines Report of Investigations 7045, $57 \mathrm{p}$.

Pratt, J. H. (1902). The mining industry in North Carolina during 1901: North Carolina Geol. Survey. Econ. Paper No. 6, $101 \mathrm{p}$.

Ramsay, W. (1898). Über die Geologische Entwicklung der Halbinsel Kola in der Quartärzeit. (About the geological evolution of the peninsula of Kola in the Quaternary period.) Fennia, 16(1), $151 \mathrm{p}$.

Ross, M. (1981). The geological occurrences and health hazards of amphibole and serpentine asbestos. In: Reviews in Mineralogy, vol 9A, Amphiboles and other hydrous pyriboles - mineralogy, ed. Veblen, DR Mineralogical Society of America, Washington.

Säntti, J., Kontinen, A., Sorjonen-Ward, P., Johanson, B., \& Pakkanen, L. (2006). Metamorphism and Chromite in Serpentinized and Carbonate-Silica-Altered Peridotites of the Paleoproterozoic Outokumpu-Jormua Ophiolite Belt, Eastern Finland. International Geology Review, 48, 494-546. https://doi.org/10.2747/0020-6814.48.6.494

Selikoff, I. J., Hammond, E. C., \& Churg, J. (1972). Carcinogenicity of amosite asbestos. Archives of Environ Health, An Internationasl Journal, 25(3), 183-186. http://dx.doi.org/10.1080/0h0039896.1972.10666158

The History of the Powhatan Mining Corporation. (September 1929). Asbestos, 11(3), 22-28.

Tossavainen, A., Karjalainen, A., \& Karhunen, P. (1994). Retention of Asbestos Fibers in the Human Body. 
Environmental health perspectives. 102 Suppl 5. 253-5.

Tuomi, T. (1992). Fibrous minerals in the lungs of mesothelioma patients: comparisons between data on SEM, TEM and personal interview information. American Journal of Industrial Medicine, 21, 155-162. https://doi.org/10.1002/ajim.4700210205

Tuomi, T., Segerberg-Konttinen, M., Tammilehto, L., Tossavainen, A., \& Vanhala, E. (1989). Mineral Fiber Concentration in Lung Tissue of Mesothelioma Patients in Finland. American Journal of Industrial Medicine, 16, 247-254. https://doi.org/10.1002/ajim.4700160303

Uibu, T. et al. (2009). Asbestos Fibers in Para-Aortic and Mesenteric Lymph Nodes. American Journal of Industrial Medicine, 52, 464-470. https://doi.org/10.1002/ajim.20694

Van Gosen, B. S. (2005). Reported Historic Asbestos Mines, Historic Asbestos Prospects, and Natural Asbestos Occurrences in the Eastern United States: U.S. Geological Survey Open-File Report 2005-1189. Retrieved from http://pubs.usgs.gov/of/2005/1189/

Van Gosen, B. S. (2007). Reported Historic Asbestos Mines, Historic Asbestos Prospects, and Natural Asbestos Occurrences in the Rocky Mountain States of the United States (Colorado, Idaho, Montana, New Mexico, and Wyoming) Open-File Report 2007-1182. Retrieved from http://pubs.usgs.gov/of/2007/1189

Van Gosen, B. S. (2008). Reported Historic Asbestos Mines, Historic Asbestos Prospects, and Natural Asbestos Occurrences in the Southwestern United States (Arizona, Nevada, and Utah) Open-File Report 2008-1095. Retrieved from http://pubs.usgs.gov/of/2007/1189

Veblen, D. R., \& Burnham, C. W. (1978) New biopyriboles from Chester, Vermont: I. Descriptive mineralogy. Am. Mineral., 63, 1000-1009.

Vilkman, S., Lahdensuo, A., Mattila, J., Tossavainen, A., \& Tuomi, T. (1993). Asbestos exposure according to different exposure indices among Finnish lung cancer patients. Int. Arch Occup Environ Heath, 65, 269-274. https://doi.org/10.1007/BF00381202

Vincent, H. R., McConnell, K. I., \& Perley, P. C. (1990). Geology of Selected mafic and ultramafic rocks of Georgia: A Review. Information Circular 82 (Atlanta 1990).

Wagner, J. C., Sleggs, C. A., \& Marchand, P. (1960). Diffuse pleural mesothelioma and asbestos exposure in the North Western Cape Province. British $J$ Industrial Medicine, 17, 260-271. https://doi.org/10.1136/oem.17.4.260

Wilk, H. B. (1953). Composition and Origin of Soapstone. Bulletin de la Commission Géologique de Finlande. No 165.

Winkler, H. G. F. (1967). The Abukuma-Type Facies Series. In book: Petrogenesis of Metamorphic Rocks. New York, springer-Verlag 220p. https://doi.org/10.1007/978-3-662-00866-9_9

\section{Copyrights}

Copyright for this article is retained by the author(s), with first publication rights granted to the journal.

This is an open-access article distributed under the terms and conditions of the Creative Commons Attribution license (http://creativecommons.org/licenses/by/4.0/). 